\title{
Optimization of the Egyptian Natural Gas Transmission Networks
}

\author{
Ahmed Safwat Nafey ${ }^{1, a}$, Nasser Zoghaib ${ }^{2, b}$, Mohamed K. Omar ${ }^{3, c^{*}}$ \\ ${ }^{1}$ Dept. of Mechanical Engineering, Faculty of Engineering, Suez University, Suez, Egypt. \\ ${ }^{2}$ Egyptian Natural Gas Company - Head office, NATA building, $5^{\text {th }}$ settlement, New Cairo District, Cairo, Egypt. \\ ${ }^{3}$ Egyptian Natural Gas Company - Suez Branch, Zaiteiat Street, Suez, Egypt.
}

\begin{abstract}
This paper aims to enhance the operation of Egyptian Natural Gas Transmission Networks. The Egyptian government categorized the industries that consume natural gas into different sectors. Each industrial sector has its own gas price. Our objective is to get the maximum revenue gained through the optimal gas distribution between these different sectors. A computer program was developed using Matlab Genetic Algorithm approach for solving the obtained nonlinear problem. This study aims to find the maximum profit from the gas distribution of the existing steady state gas grid. All Required demands, sources capacities and pressure limitations are constraints of the objective function.

The obtained gas grid analysis data are compared and verified with SYNERGI software [1]. The results show the higher profit which can be gained by enhancing Egyptian gas grid. The obtained results confirm that increasing gas delivery amounts does not necessarily mean higher economic benefits. It is found also that the gained profit affected by several operation parameters. It was concluded that source gas price and pressure values of gas feeder directly affect the economic benefits.
\end{abstract}

Keywords: Natural gas pipeline network; Genetic Algorithm; Cost; Steady-state; Optimization

\section{INTRODUCTION}

The Natural gas is a fossil fuel like crude oil and coal, which consists of a mixture of hydrocarbon gases. The Egyptian natural gas networks have a significant impact on the Egyptian economy. Natural Gas started in the Egyptian market in 1975 when the first natural gas field ABU MADI was put on stream [2]. Now, Egypt occupies the $16^{\text {th }}$ place in the list of dry natural gas production countries with 51 billion cubic meters annually according to Energy Information Administration (EIA) - 2017 Rank [3]

The gas transmission network in Egypt is considered as one of the largest and longest gas transmission pipeline networks in Africa and in the Middle East [4]. It delivered about 225 million standard cubic meters of natural gas per day by the end of year 2017, compared to 37 MMSCMD in 1997 [4]. There are many researches on gas network modelling and simulation such as Herra'n-Gonza'lez et al. [5] \& Peng Shanbi et al. [6].

Some studies focus on a part of gas network already existing for optimizing the grid, such as operation of existing compressors stations, available supplies and required demands. Examples of studies on this type of optimization are done by Alexander Martin et al. [7].They described a technique for approximating the nonlinearities in equations to a piece-wise linear. The developed model aims to compensate the pressure loss in the network by running the compressors with cost-efficiently manner. All demands are satisfied with the required pressure.

Similarly, due to the variety of natural gas sources, Daniel De Wolf \& Yves Smeers [8] formulated a nonlinear model to minimize the total cost of supplied gas. The developed model used to determine the amounts of gas contributing from each source in the grid. All required demands are satisfied. A simplex algorithm is used for solving a linear piecewise approximation problem.

Herbert de Mélo Duarte et al. [9] considered the optimal design for constructing a new gas network with required constraints. A tabu search algorithm is used for solving 
nonlinear mixed integer problem. The goal is to determine the best design for gas distribution networks. Minimum pressure requirements, topology, environmental risks and economics are considered in the model

Also, Jean-Michel Guldmann \& Fahui Wang [10] used mixed integer linear programing method to find a solution for minimizing the total cost of gas supply as source prices are variable and depends on several criteria. They found that the weather is the basic factor that affects the demands for gas and the price of supply source.

Similarly, Zoghaib N.A et al. [11] formulated a linear programing model to find a solution for minimizing the total operating cost of a gas network. They used a simplex algorithm for solving the formulated model

In Egypt, the natural gas consumers are categorized into seven different sectors [12]. Each industrial sector has its own sales gas price. Commitment to distribute gas to consumers of different prices offers a challenge to obtain the maximum revenue. The objective of this study is to find a mathematical solution to achieve this maximum revenue regarding the following constraints:
a) Available capacities of gas sources,
b) Allowable demand range of gas consumers, and
c) Sustaining allowable gas pressures.

\section{OPTIMIZATION OF NATURAL GAS GRID}

\section{II.I Natural Gas Grid}

At first, there was a need to simplify the Egyptian Gas Grid to ease handling it mathematically. This was done by collecting near-by small consumers in one large consumer. This trend simplified the calculations but didn't affect the accuracy of the results with a considerable degree. Fig. 1 represents it in a simplified steady-state scheme. The simplified grid contains 17 nodes representing 68 customers "each node represents four different customers" and three supply sources. The grid consists of 24 transmission pipelines with different diameters and lengths according to table 1. Although the actual Egyptian Gas Grid is more complicated than that was handled by our study, the used optimization and analysis methods are applicable for any network topology.

\section{II.II Objective function}

The Egyptian government divided natural gas consumers to seven sectors which are electricity, fertilizers, cement, petroleum, chemicals, refractories and car-home supply stations. Natural gas is sold to each industrial sector with a different price. For example the price of natural gas supplied to electric power plants is $3 \$$ MMBTU, while it is 7 \$/MMBTU for cement factories as shown in table 2 [12].

Maximization of the economic gained benefit is the objective of this study. This target can be achieved by maximizing the difference between the gas sales income and the cost of gas purchasing in addition to the cost associated with transportation. This objective function can be represented as:

$$
\begin{aligned}
\max & \text { Profit }=\sum_{\mathrm{t}}\left\{\mathrm{X}_{\mathrm{t}} \times \text { Fgas }_{\mathrm{t}} \times \beta\right\} \\
- & \sum_{\mathrm{m}} \sum_{\mathrm{i}}\left\{\text { Sgas }_{\mathrm{mi}} \times \text { Fsrc } \times \beta\right\}-\sum_{\mathrm{i}} \sum_{\mathrm{j}}\left\{\mathrm{Q}_{\mathrm{ij}} \times \text { Fope } \times \beta\right\}
\end{aligned}
$$

Where,

$$
\begin{aligned}
& \text { Fgas }_{t}=\text { Price of sold-gas for customer t (\$MMBTU) } \\
& \text { Fope }=\text { Transportation Tariff (\$/MMBTU) } \\
& \text { Fsrc = Price of gas from supply point } \mathrm{m} \text { (\$/MMBTU) } \\
& Q_{i j} \quad=\text { Total Amount of flow from node } \mathrm{i} \text { to node } \mathrm{j}(\mathrm{Sm} 3 / \mathrm{h}) \\
& X_{t} \quad=\text { Amount of gas supplied to customer } \mathrm{t}(\mathrm{Sm} 3 / \mathrm{h}) \\
& \operatorname{Sgas}_{m i}=\text { Amount of gas flow from supply point } \mathrm{m} \text { to node } \mathrm{i} \\
& \text { (Sm3/h) } \\
& \beta=\text { Conversion Factor (MMBTU/Sm3) } \\
& \mathrm{j} \quad=\text { Any node } \mathrm{j} \\
& \mathrm{i} \quad=\text { Another node apart from node } \mathrm{j} \\
& \mathrm{t} \quad=\text { Any customer } \\
& \mathrm{m} \quad=\text { Any supply point }
\end{aligned}
$$




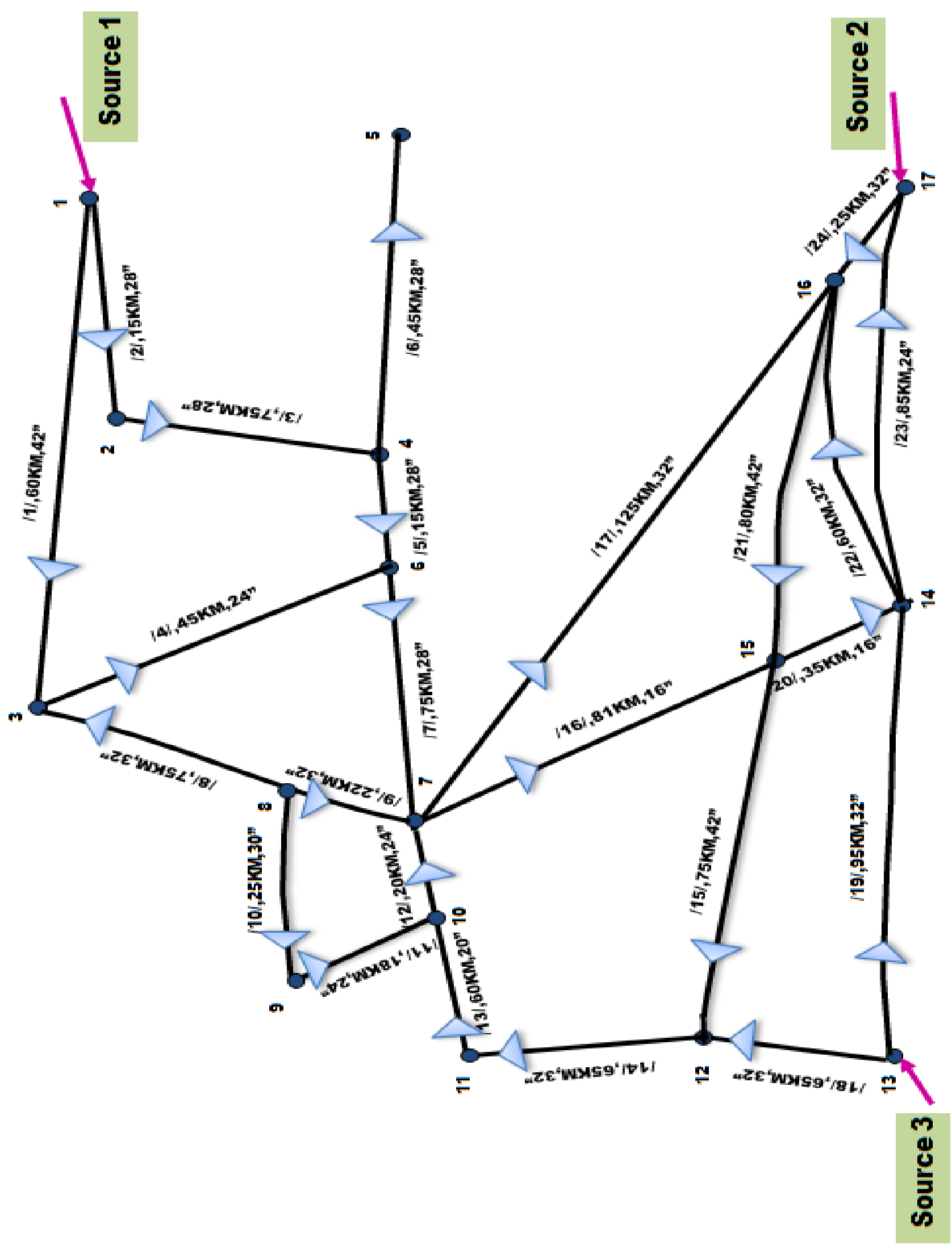

Fig. 1. A schematic of a natural gas grid. 
International Journal of Engineering Research and Technology. ISSN 0974-3154, Volume 13, Number 9 (2020), pp. 2347-2358

(C) International Research Publication House. https://dx.doi.org/10.37624/IJERT/13.9.2020.2347-2358

Table 1. List of diameters and lengths for the transmission pipelines of Fig. 1.

\begin{tabular}{|c|c|c|}
\hline $\begin{array}{l}\text { Pipeline } \\
\text { number }\end{array}$ & Length $(\mathrm{Km})$ & Diameter (inch) \\
\hline 1 & 60 & 42 \\
\hline 2 & 15 & 28 \\
\hline 3 & 75 & 28 \\
\hline 4 & 45 & 24 \\
\hline 5 & 15 & 28 \\
\hline 6 & 45 & 28 \\
\hline 7 & 75 & 28 \\
\hline 8 & 75 & 32 \\
\hline 9 & 22 & 32 \\
\hline 10 & 25 & 30 \\
\hline 11 & 18 & 24 \\
\hline 12 & 20 & 24 \\
\hline 13 & 60 & 20 \\
\hline 14 & 65 & 32 \\
\hline 15 & 75 & 42 \\
\hline 16 & 81 & 16 \\
\hline 17 & 125 & 32 \\
\hline 18 & 65 & 32 \\
\hline 19 & 95 & 32 \\
\hline 20 & 35 & 16 \\
\hline 21 & 80 & 42 \\
\hline 22 & 60 & 32 \\
\hline 23 & 85 & 24 \\
\hline 24 & 25 & 32 \\
\hline
\end{tabular}

\section{II.III Constraints}

- Gas flow conservation for each node:

\{Supply of gas at node $\mathrm{i}+$ total inflow to node $\mathrm{i}-$ total outflow from node $\mathrm{i}\}=$ Demands at node $\mathrm{i}$
a. $\quad \sum_{\mathrm{m}} \operatorname{Sgas}_{\mathrm{mi}}+\sum_{\forall \mathrm{i}} \mathrm{Q}_{\mathrm{ji}}-\sum_{\mathrm{j}} \mathrm{Q}_{\mathrm{ij}}=\mathrm{D}_{\mathrm{i}}$
b. $\quad \sum_{\mathrm{m}, \mathrm{i}} \operatorname{Sgas}_{\mathrm{mi}}=\sum_{\mathrm{i}} \mathrm{D}_{\mathrm{i}}$

\section{- Supply Capacity Constraint}

Each supply point has a minimum \& maximum capacity that cannot be exceeded

$$
\operatorname{Cmin}_{\mathrm{m}} \leq \sum_{\mathrm{i}} \operatorname{Sgas}_{\mathrm{mi}} \leq \operatorname{Cmax}_{\mathrm{m}} \forall \mathrm{m}
$$

- $\quad$ Non-Negative Constraints

The following variables are physical variable, so they can't be negative

$$
\begin{gathered}
\mathrm{D}_{\mathrm{j}} \geq 0 \\
\operatorname{Sgas}_{\mathrm{mi}} \geq 0 \\
\mathrm{Q}_{\mathrm{ij}} \geq 0 \\
\mathrm{X}_{\mathrm{t}} \geq 0 \\
\mathrm{P}_{\mathrm{i}} \geq 0
\end{gathered}
$$

- demands limitation:

Each customer has a minimum \& maximum capacity that cannot be exceeded

$$
\operatorname{dmin}_{\mathrm{t}} \leq \mathrm{X}_{\mathrm{t}} \leq \operatorname{dmax}_{\mathrm{t}} \quad \forall \mathrm{t}
$$

Where,

$$
\begin{array}{ll}
\min _{t}= & \begin{array}{l}
\text { Minimum required demand for } \\
\text { customer } \mathrm{t}(\mathrm{Sm} 3 / \mathrm{h})
\end{array} \\
\max _{t} n= & \text { Maximum required demand for } \\
& \text { customer } \mathrm{t}(\mathrm{Sm} 3 / \mathrm{h})
\end{array}
$$




\section{II.IV Unit cost, design and Operating parameter}

Gas sales prices and the operating parameters are indicated in table 2

Table 2. Unit cost, design and operating parameters

\begin{tabular}{|c|c|}
\hline Parameter & Value $[12,14]$ \\
\hline $\begin{array}{l}\text { customer A (Electricity)gas } \\
\text { sales price }\end{array}$ & $\$ 3 / \mathrm{MMBTU}$ \\
\hline $\begin{array}{l}\text { customer B (Fertilizer)gas } \\
\text { sales price }\end{array}$ & $\$ 4.5 / \mathrm{MMBTU}$ \\
\hline $\begin{array}{l}\text { customer } \mathrm{C}(\text { cement/steel }) \\
\text { gas sales price }\end{array}$ & $\$ 7 / \mathrm{MMBTU}$ \\
\hline $\begin{array}{l}\text { customer D (others)gas sales } \\
\text { price }\end{array}$ & $\$ 5 / \mathrm{MMBTU}$ \\
\hline $\begin{array}{l}\text { customer } \mathrm{E} \text { (petroleum) gas } \\
\text { sales price }\end{array}$ & $\$ 5 / \mathrm{MMBTU}$ \\
\hline $\begin{array}{l}\text { customer } \mathrm{F} \\
\text { (petrochemical)gas sales } \\
\text { price }\end{array}$ & $\$ 4.5 / \mathrm{MMBTU}$ \\
\hline $\begin{array}{l}\text { customer } \mathrm{G} \text { (car/home } \\
\text { station) gas sales price }\end{array}$ & \$ 4 /MMBTU \\
\hline Transmission tariff & $\$ 0.38$ / MMBTU \\
\hline $\begin{array}{l}\text { Purchasing gas price } \\
\text { (an average price } \\
\text { assumption) }\end{array}$ & \$ 3 / MMBTU \\
\hline$\beta @ \mathrm{Cv}=1060 \mathrm{BTU} / \mathrm{ft} 3$ & 0.0374 \\
\hline The flowing Temperature & $20 \square \mathrm{C}$ \\
\hline $\begin{array}{l}\text { Grid reference pressure } \\
\text { (node 17) }\end{array}$ & $7000 \mathrm{Kpa}$ \\
\hline $\begin{array}{l}\text { Gas average specific gravity } \\
\text { (G) }\end{array}$ & 0.61 \\
\hline Friction Factor & 0.01 \\
\hline Compressibility (Z) & 0.9 \\
\hline Base Pressure & $101.35 \mathrm{Kpa}$ \\
\hline Base Temperature & $15 \square \mathrm{C}$ \\
\hline Internal pipe design pressure & 77 arg \\
\hline
\end{tabular}

\section{OTIMIZATION USIBG GENETIC ALGORITHM}

The major advantage of traditional search techniques such as Sequential Quadratic Programming (SQP) is that they are not a feasible point method. The initial point is not necessary to be a feasible point that satisfies all of the constraints of NLP. Finding an initial a feasible point may be harder than solving the main problem itself [15]

The major disadvantage of SQP method is that it can be trapped by local minimum point especially if the objective function is noisy. Genetic Algorithm (GA) can overcome all of disadvantages related to traditional search techniques. As GA has the ability to search in the space of solutions to find the required point with high chance of success. Also, GA can deal with discrete in addition to continuous nonlinear optimization problems and has a high successful probability for overcoming the local minimum trapped problem [16].

\section{VALIDATION}

To examine the validity of hydraulic analysis for developed program, the calculated results of pressure/flow are compared with the obtained results of SYNERGI software [1]. The comparison shows that the max deviation between developed program results and SYNERGI in pressure analysis is only $1.615593266 \%$ and only $-0.008675911 \%$ in the flow analysis. This is shown in details in appendix A

\section{RESULTS}

\section{V.I Effects of increasing gas delivery amounts}

The results show that distributing the maximum limits of required demands are not the optimum solution for increasing the gained profit. Table 3 shows the gained profit from gas grid in the following cases:

- Using genetic algorithm approach to enhance the gas grid.

- The maximum demand for each customer is met.

\section{V.II Effects of Feeder pressure on obtained profits}

Results indicate that for every $100 \mathrm{Kpa}$ increase in pressure of node 17(reference pressure) more profit are achieved. But for increasing the pressure of node 17 above 7200 $\mathrm{Kpa}$, the profits will not change a lot.

These results are indicated in Fig. 2 ( $@ \mathrm{Cv}=1060 \mathrm{BTU} / \mathrm{ft} 3$, source gas price $=3 \$ / \mathrm{MMBTU}$ ), which shows the increase in profits, as well as the profit gained compared to profit if the maximum demand for each customer is met 


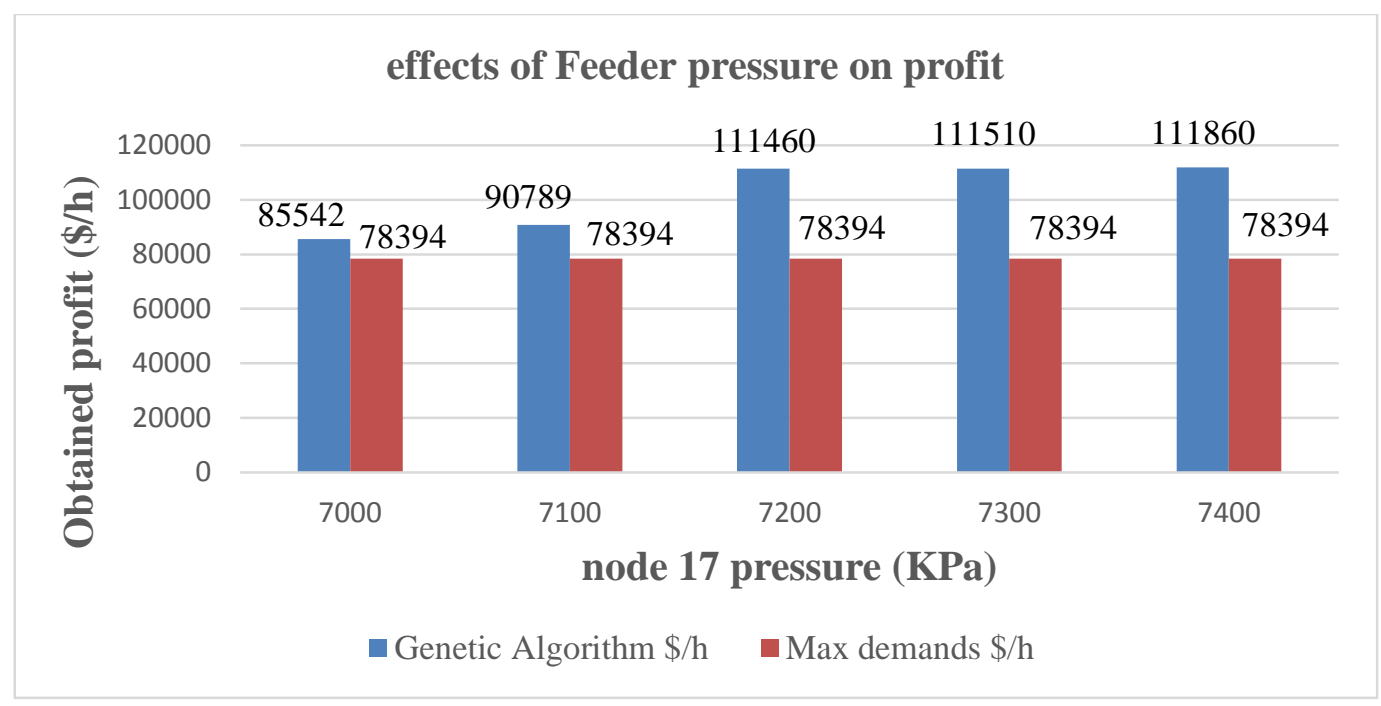

Fig. 2. Effects of node 17 pressure on profit

Table 3. Comparison between gained profits in different cases

\begin{tabular}{|c|c|c|c|}
\hline & Genetic Algorithm & Maximum demands & Parameters \\
\hline \multirow{3}{*}{$\sum_{\substack{\infty \\
0}}^{\infty}$} & 111460 & 78394 & $\begin{array}{c}\mathrm{Cv}=1060 \mathrm{BTU} / \mathrm{ft} 3 \\
\text { source gas price }=3 \$ / \mathrm{MMBTU} \\
\text { node } 17 \text { pressure }(\text { reference })=7200 \mathrm{Kpa}\end{array}$ \\
\hline & 135000 & 115000 & $\begin{array}{c}\mathrm{Cv}=1050 \mathrm{BTU} / \mathrm{ft} 3 \\
\text { source gas price }=2.9 \$ / \mathrm{MMBTU} \\
\text { node } 17 \text { pressure (reference) }=7000 \mathrm{Kpa}\end{array}$ \\
\hline & 166000 & 152000 & $\begin{array}{c}\mathrm{Cv}=1050 \mathrm{BTU} / \mathrm{ft} 3 \\
\text { source gas price }=2.8 \$ / \mathrm{MMBTU} \\
\text { node } 17 \text { pressure }(\text { reference })=7000 \mathrm{Kpa}\end{array}$ \\
\hline
\end{tabular}

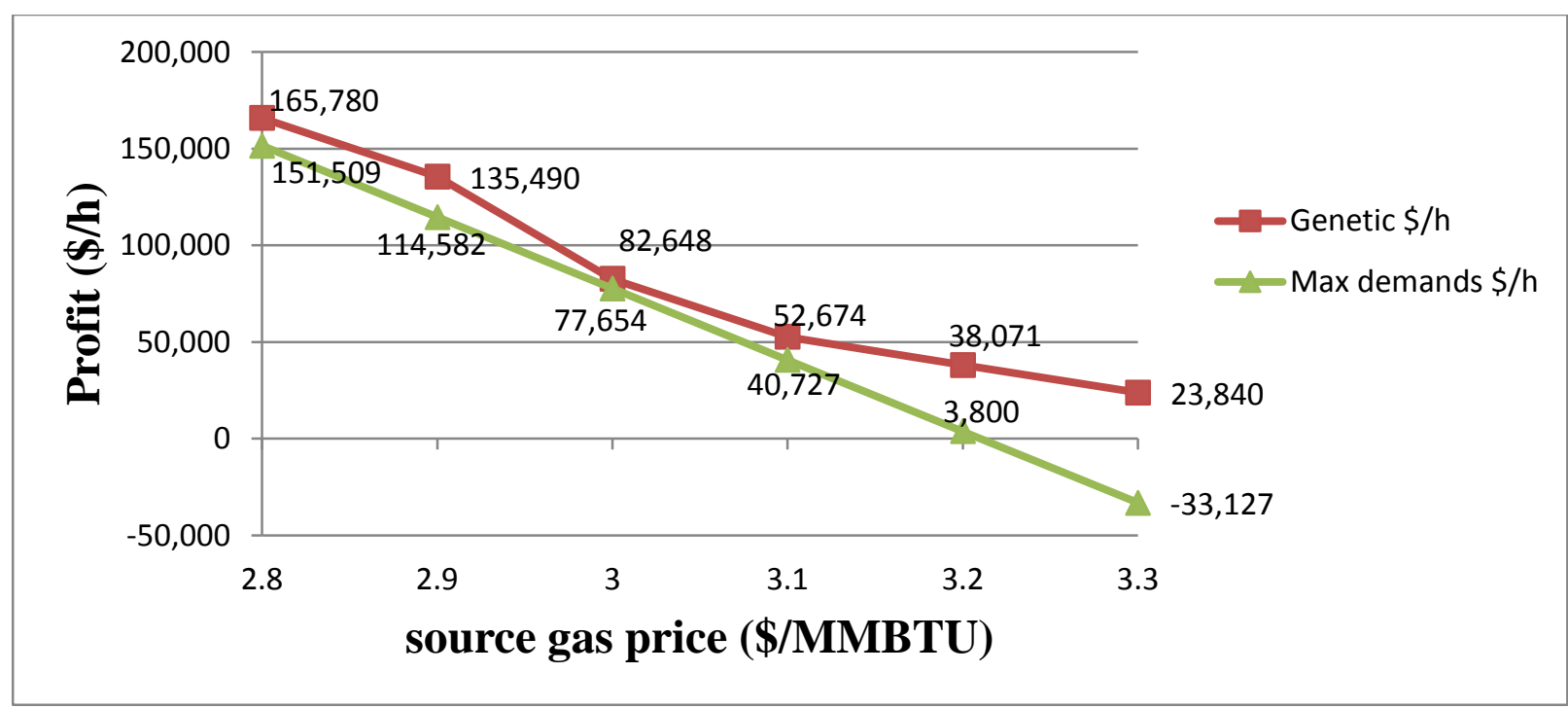

Fig. 3. Effects of source gas price on profit 


\section{V.III THE EFFECTS OF CHANGING THE GAS PRICE FROM SOURCES ON PROFITS}

The results illustrated that as the price of gas from sources increases, profits will be negatively affected. The developed program can predict the maximum profit that can be achieved at different gas prices

These results are indicated in Fig. 3 (@ CV=1050BTU/ft3, node 17 pressure $=7000 \mathrm{Kpa}$ ), which shows the decrease in profit due to increase in the source gas price.

Also, a comparison between profit gained from optimizing the gas distributed and the profit gained if the maximum demand for each customer is met.

\section{DISCUSSION OF THE RESULTS}

The obtained profit from the operation of gas network was found to be affected by many parameters such as the distributed quantities, source gas price and pressure of gas feeder. Distributing the maximum limits of required demands are not the optimum solution for increasing the gained profit. As illustrated in table 3 , the obtained profit always higher in case of using genetic algorithm than increasing the distributed quantities.

According to Fig. 3, the results show that in case of source gas price is 2.9 \$MMBTU the obtained profit can reach 135000 $\$ / \mathrm{h}$ due to optimization of gas grid. However, only $115000 \$ / \mathrm{h}$ was gained when the maximum limits of required demands was distributed. Therefore, an increase in profit of $17 \%$ was obtained in the case of optimization. A comparison between gained profit due to optimization of gas grid, and the resulting profits if the maximum demand for each customer is met (@ $\mathrm{CV}=1090 \mathrm{BTU} / \mathrm{ft} 3$ \& P17 =7000 Kpa, Fsrc=3\$/MMBTU) are showed in details in appendix C \& D.

Also Fig. 2 shows that by increasing the feeder gas pressure of source no. 2, the obtained profit increases until the pressure reach 7200 KPA. Further increase in pressure will not add any extra profit.

\section{CONCLUSIONS}

In this study, a mathematical model was developed for a natural gas transmission network. Depending on the methodology of Egyptian gas pricing, the optimum profit is evaluated using Matlab Genetic Algorithm Approach. Required demands, sources capacities and pressure limitation are constraints of the objective function. The following conclusions were obtained:

1. The genetic algorithm is an efficient tool for optimizing the operation of Egyptian Gas grid [17].

2. Distributing the maximum limits of required demands are not the optimum solution for increasing the gained profit as illustrated in table 3.The obtained results confirm that increasing gas delivery amounts do not necessarily mean higher economic benefits [13].

3. Increasing the feeder's pressure positively affects the obtained profit until a certain limit. In this model, the profit will not be affected by increasing the pressure of source 2 (node 17) more than $7200 \mathrm{Kpa}$ as shown in Fig. 2.This will make future decision for installing a compressor station in network more reliable [18].

4. Increasing the price of gas source negatively affects the obtained profit. But the profit gained from the optimization is still greater than the profit if the maximum demand for each customer is met.

\section{REFERENCES}

[1] Information on https://www.dnvgl.com/services/ pipeline-integrity-management-software-synergipipeline-1363

[2] Information on https://www.egas.com.eg/historynatural-gas-industry

[3] Information on https://www.eia.gov/international/data /country/EGY

[4] Information on http://www.gasco.com.eg/? page_id=374

[5] Herra'n-Gonza'lez, J.M. De La Cruz, B. De Andre'sToro, J.L. Risco-Martin. (2008). Modeling and Simulation of a Gas Distribution Pipeline Network.ElSEVIER. Department of Computer Architecture and Automatic Control, Complutense University, 28040 Madrid, Spain

[6] Peng Shanbi, Li Junying, Jiang Yong and Liu Yuan. (2013). The Simulation of Natural Gas Gathering Pipeline Network. the Open Fuels \& Energy Science Journal, 2013, 6, 18-22

[7] Alexander Martin,Markus M“oller,Susanne Moritz.(2005). Mixed Integer Models for the Stationary Case of Gas Network Optimization

[8] Daniel De Wolf \& Yves Smeers. (1999). The Gas Transmission Problem Solved by an Extension of the Simplex Algorithm

[9] Herbert de Mélo Duarte, Elizabeth F, Gouvêa Goldbarg, and Marco César Goldbarg. (2006). A Tabu Search Algorithm for Optimization of Gas Distribution Networks

[10] Jean-Michel Guldmann, Fahui Wang. (1997). Optimizing the Natural Gas Supply Mix of local Distribution Utilities

[11] Zoghaib N.A et al.,Planning of Gas Pipeline Networks, the $6^{\text {th }}$ Syrian-Egyptian petroleum and chemical Engineering conference ,November 2005 ,Homs ,Syria

[12] Egyptian Gas pricing Law no. 1162 for year 2014

[13] Xia Wu, Changjun Li, Yufa He, Wenlong Jia. (2018). Operation Optimization of Natural Gas Transmission Pipelines Based on Stochastic Optimization Algorithms. (Article ID 1267045). Hindawi. Mathematical Problems in Engineering. 
International Journal of Engineering Research and Technology. ISSN 0974-3154, Volume 13, Number 9 (2020), pp. 2347-2358

(C) International Research Publication House. https://dx.doi.org/10.37624/IJERT/13.9.2020.2347-2358

[14] Law for gas market activities regulations issued with no. 196 of year 2017

[15] Paul T. Boggs , (1996), Sequential Quadratic Programing, Department of mathematics and operation research, University of North Carolina

[16] Alaa Sheta, HamzaTurabieh , (2006) ,A Comparison Between Genetic Algorithms and Sequential Quadratic Programming in Solving Constrained Optimization Problems, AIML Journal, Volume (6), Issue (1)
[17] Shahin islam et al., (2008), GAS DISTRIBUTION NETWORK OPTIMIZATION BY GENETIC ALGORITHM, Ninth International Congress of Fluid Dynamics \& Propulsion, ICFDP9-EG-290

[18] Rainer Kurz et al.,(2012), Gas Compressor Station Economic Optimization, International Journal of Rotating Machinery, Volume 2012, Article ID 715017

\section{APPENDIX A}

Table (A1): Flow rate comparison between the developed program and Synergi

\begin{tabular}{|c|c|c|c|c|}
\hline \multirow{2}{*}{ line } & \multirow{2}{*}{$\begin{array}{l}\text { From pnt } \\
\text { to pnt }\end{array}$} & Developed program & Synergi program & deviation \\
\hline & & $\mathrm{Q}_{\mathrm{n}} \mathrm{Sm} 3 / \mathrm{h}$ & $\mathrm{Q}_{\mathrm{n}} \mathrm{Sm} 3 / \mathrm{h}$ & $\Delta \mathrm{Q}_{\mathrm{n} \%}$ \\
\hline 1 & 1 to 3 & 1931169.5 & 1931169.1 & $-2.25259 \mathrm{E}-05$ \\
\hline 2 & 1 to 2 & 1603924.4 & 1603924.3 & $-5.65441 \mathrm{E}-06$ \\
\hline 3 & 2 to 4 & 723848.8 & 723848.8 & $-7.32505 \mathrm{E}-06$ \\
\hline 4 & 3 to 6 & 701684.1 & 701684.0 & $-1.59439 \mathrm{E}-05$ \\
\hline 5 & 4 to 6 & -187919.4 & -187919.3 & $-5.45633 \mathrm{E}-05$ \\
\hline 6 & 4 to 5 & 220930.2 & 220930.2 & $-1.42192 \mathrm{E}-06$ \\
\hline 7 & 6 to 7 & 2096.6 & 2096.4 & -0.008675911 \\
\hline 8 & 8 to 3 & -1113712.2 & -1113712.3 & $9.55013 \mathrm{E}-06$ \\
\hline 9 & 8 to 7 & 124349.9 & 124349.7 & -0.000181309 \\
\hline 10 & 8 to 9 & 335092.7 & 335092.6 & $-1.20037 \mathrm{E}-05$ \\
\hline 11 & 9 to 10 & 85492.7 & 85492.6 & $-7.61661 \mathrm{E}-05$ \\
\hline 12 & 10 to 7 & -220307.3 & -220307.3 & 8.91104E-06 \\
\hline 13 & 11 to 10 & -189300.1 & -189300.2 & $3.70812 \mathrm{E}-05$ \\
\hline 14 & 12 to 11 & 491608.8 & 491608.9 & $1.61152 \mathrm{E}-05$ \\
\hline 15 & 15 to 12 & 324290.8 & 324290.8 & $4.83376 \mathrm{E}-06$ \\
\hline 16 & 7 to 15 & 58602.1 & 58602.1 & $-9.66813 \mathrm{E}-05$ \\
\hline 17 & 7 to 16 & -305033.6 & -305033.2 & -0.000107683 \\
\hline 18 & 13 to 12 & 357606.9 & 357607.1 & $4.62735 \mathrm{E}-05$ \\
\hline 19 & 13 to 14 & -373625.4 & -373625.5 & $2.67534 \mathrm{E}-05$ \\
\hline 20 & 15 to 14 & -132115.1 & -132115.1 & $-3.41326 \mathrm{E}-05$ \\
\hline 21 & 16 to 15 & 999810.9 & 999811.0 & $4.82635 \mathrm{E}-06$ \\
\hline 22 & 14 to 16 & -128012.1 & -128012.2 & $4.91807 \mathrm{E}-05$ \\
\hline 23 & 14 to 17 & -576836.3 & -576836.2 & $-2.07525 \mathrm{E}-05$ \\
\hline 24 & 17 to 16 & 2174403.3 & 2174403.5 & $1.1371 \mathrm{E}-05$ \\
\hline
\end{tabular}

- Deviation $\%=$

(Qn from synergi program- Qn from developed program) / Qn from developed program 
International Journal of Engineering Research and Technology. ISSN 0974-3154, Volume 13, Number 9 (2020), pp. 2347-2358

(C) International Research Publication House. https://dx.doi.org/10.37624/IJERT/13.9.2020.2347-2358

Table (A2): pressure comparison between the developed program and Synergi

\begin{tabular}{|c|c|c|c|}
\hline \multirow{2}{*}{ node } & Developed program & Synergi program & deviation \\
\cline { 2 - 4 } & pressure KPA & pressure KPA & $\Delta$ Pressure \% \\
\hline 1 & 7406.55644 & 7399.7 & 0.092572575 \\
\hline 2 & 5818.955982 & 5795.9 & 0.396221962 \\
\hline 3 & 6230.835049 & 6331.5 & -1.615593266 \\
\hline 4 & 3532.432956 & 3548.1 & -0.443519935 \\
\hline 5 & 3359.00967 & 3370.3 & -0.336120784 \\
\hline 6 & 3572.996788 & 3597.3 & -0.680191255 \\
\hline 7 & 3572.971686 & 3602 & -0.812441755 \\
\hline 8 & 3586.232922 & 3621.8 & -0.991767086 \\
\hline 9 & 3432.090397 & 3467.5 & -1.031721164 \\
\hline 10 & 3409.475045 & 3442.7 & -0.974488864 \\
\hline 11 & 2309.227607 & 2307.6 & 0.070482759 \\
\hline 12 & 3117.162994 & 3132.3 & -0.485602014 \\
\hline 13 & 3469.374047 & 3470 & -0.018042244 \\
\hline 14 & 3967.07217 & 3949.9 & 0.432867594 \\
\hline 15 & 3206.535315 & 3219.3 & -0.398083394 \\
\hline 16 & 4001.507764 & 3984.7 & 0.420035759 \\
\hline 17 & 7000 & 7000 & 0 \\
\hline & & & \\
\hline
\end{tabular}

- Deviation \%=

(P from synergi program- $\mathrm{P}$ from developed program) / $\mathrm{P}$ from developed program

\section{APPENDIX B}

Table (B1): The obtained results from the gas grid optimization (node 17=7000KPA, Fsrc=3\$/MMBTU,Cv=1090 BTU/ft3)

\begin{tabular}{|c|c|c|c|c|c|c|c|c|c|}
\hline & & $\min$ & $\max$ & $\begin{array}{l}\text { Opt. } \\
\text { results }\end{array}$ & & & $\min$ & $\max$ & Opt. results \\
\hline \multirow{4}{*}{ 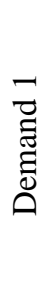 } & A & 600,000 & $1,000,000$ & 600000 & \multirow{4}{*}{ 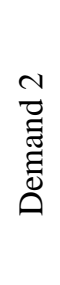 } & $\mathrm{B}$ & $500,000.00$ & $700,000.00$ & 695581 \\
\hline & $\mathrm{C}$ & $40,000.00$ & $50,000.00$ & 50000 & & $\mathrm{D}$ & $50,000.00$ & $65,000.00$ & 64996 \\
\hline & $\mathrm{E}$ & $30,000.00$ & $34,000.00$ & 34000 & & $\mathrm{~F}$ & $100,000.00$ & $113,000.00$ & 113000 \\
\hline & $\mathrm{D}$ & $1,000.00$ & $1,500.00$ & 1500 & & G & $5,000.00$ & $6,500.00$ & 6499 \\
\hline \multirow{4}{*}{ 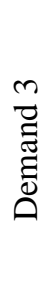 } & $\mathrm{C}$ & $40,000.00$ & $43,000.00$ & 43000 & \multirow{4}{*}{ 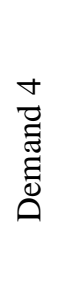 } & $\mathrm{D}$ & $9,000.00$ & $15,000.00$ & 15000 \\
\hline & $\mathrm{E}$ & $15,000.00$ & $20,000.00$ & 20000 & & $\mathrm{~F}$ & $50,000.00$ & $70,000.00$ & 69999 \\
\hline & $\mathrm{G}$ & $40,000.00$ & $60,000.00$ & 50273 & & A & $600,000.00$ & $800,000.00$ & 605038 \\
\hline & $\mathrm{D}$ & $2,000.00$ & $2,500.00$ & 2500 & & G & 800.00 & $1,200.00$ & 800 \\
\hline \multirow{3}{*}{ 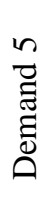 } & $\mathrm{E}$ & $12,000.00$ & $16,000.00$ & 16000 & \multirow{3}{*}{ 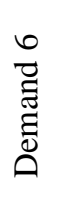 } & $\mathrm{F}$ & $120,000.00$ & $150,000.00$ & 150000 \\
\hline & G & $40,000.00$ & $55,000.00$ & 54986 & & A & $200,000.00$ & $300,000.00$ & 280672 \\
\hline & $\mathrm{B}$ & $100,000.00$ & $150,000.00$ & 147144 & & $\mathrm{C}$ & $70,000.00$ & $75,000.00$ & 75000 \\
\hline
\end{tabular}


International Journal of Engineering Research and Technology. ISSN 0974-3154, Volume 13, Number 9 (2020), pp. 2347-2358 (C) International Research Publication House. https://dx.doi.org/10.37624/IJERT/13.9.2020.2347-2358

\begin{tabular}{|c|c|c|c|c|c|c|c|c|c|}
\hline & & $\min$ & $\max$ & $\begin{array}{c}\text { Opt. } \\
\text { results }\end{array}$ & & & $\min$ & $\max$ & Opt. results \\
\hline & $\mathrm{D}$ & $2,500.00$ & $2,800.00$ & 2800 & & $\mathrm{G}$ & $5,000.00$ & $6,000.00$ & 5996 \\
\hline \multirow{4}{*}{ 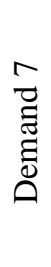 } & $\mathrm{G}$ & $30,000.00$ & $35,000.00$ & 34996 & \multirow{4}{*}{ 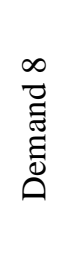 } & A & $500,000.00$ & $800,000.00$ & 535223 \\
\hline & $\mathrm{B}$ & $60,000.00$ & $100,000.00$ & 99974 & & $\mathrm{C}$ & $40,000.00$ & $60,000.00$ & 60000 \\
\hline & $\mathrm{D}$ & $15,000.00$ & $16,500.00$ & 16500 & & $\mathrm{E}$ & $50,000.00$ & $55,000.00$ & 55000 \\
\hline & $\mathrm{F}$ & 800.00 & $1,100.00$ & 1100 & & $\mathrm{G}$ & $3,000.00$ & $4,500.00$ & 4047 \\
\hline \multirow{4}{*}{ 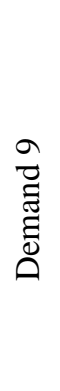 } & $\mathrm{B}$ & $50,000.00$ & $60,000.00$ & 60000 & \multirow{4}{*}{ 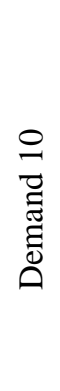 } & $\mathrm{C}$ & $60,000.00$ & $63,000.00$ & 63000 \\
\hline & $\mathrm{D}$ & $40,000.00$ & $43,000.00$ & 43000 & & $\mathrm{E}$ & $15,000.00$ & $19,000.00$ & 19000 \\
\hline & $\mathrm{F}$ & $130,000.00$ & $145,000.00$ & 145000 & & $\mathrm{G}$ & $27,000.00$ & $30,000.00$ & 30000 \\
\hline & $\mathrm{G}$ & $1,200.00$ & $1,600.00$ & 1600 & & $\mathrm{D}$ & $4,000.00$ & $4,500.00$ & 4500 \\
\hline \multirow{4}{*}{ 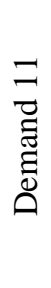 } & $\mathrm{D}$ & $8,000.00$ & $9,000.00$ & 8003 & \multirow{4}{*}{ 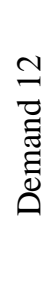 } & $\mathrm{E}$ & $10,000.00$ & $14,000.00$ & 14000 \\
\hline & $\mathrm{F}$ & $70,000.00$ & $80,000.00$ & 72006 & & G & $40,000.00$ & $45,000.00$ & 40000 \\
\hline & A & $600,000.00$ & $1,000,000.00$ & 600000 & & B & $100,000.00$ & $150,000.00$ & 135289 \\
\hline & $\mathrm{G}$ & 900.00 & $1,300.00$ & 900 & & $\mathrm{D}$ & 500.00 & $1,000.00$ & 1000 \\
\hline \multirow{4}{*}{ 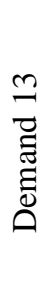 } & $\mathrm{F}$ & $54,000.00$ & $60,000.00$ & 60000 & \multirow{4}{*}{ 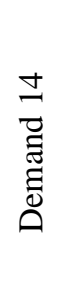 } & G & $10,000.00$ & $11,000.00$ & 10000 \\
\hline & A & $800,000.00$ & $1,000,000.00$ & 926751 & & B & $80,000.00$ & $120,000.00$ & 119107 \\
\hline & $\mathrm{C}$ & $40,000.00$ & $48,000.00$ & 48000 & & $\mathrm{D}$ & $50,000.00$ & $60,000.00$ & 60000 \\
\hline & $\mathrm{G}$ & $1,500.00$ & $1,800.00$ & 1800 & & A & $10,000.00$ & $30,000.00$ & 10000 \\
\hline \multirow{4}{*}{ 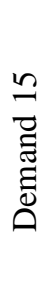 } & A & $500,000.00$ & $1,000,000.00$ & 808660 & \multirow{4}{*}{ 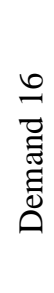 } & B & $34,000.00$ & $38,000.00$ & 38000 \\
\hline & $\mathrm{C}$ & $37,000.00$ & $43,000.00$ & 43000 & & $\mathrm{D}$ & $1,200.00$ & $1,500.00$ & 1500 \\
\hline & $\mathrm{E}$ & $12,000.00$ & $14,000.00$ & 14000 & & $\mathrm{~F}$ & $80,000.00$ & $85,000.00$ & 84907 \\
\hline & G & 500.00 & 850.00 & 578 & & A & $600,000.00$ & $850,000.00$ & 617139 \\
\hline \multirow{4}{*}{ 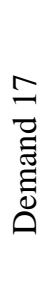 } & $\mathrm{C}$ & $41,500.00$ & $44,000.00$ & 44000 & & & & & \\
\hline & $\mathrm{E}$ & $13,000.00$ & $15,000.00$ & 15000 & & & & & \\
\hline & G & $50,000.00$ & $60,000.00$ & 50002 & & & & & \\
\hline & $\mathrm{D}$ & $1,200.00$ & $1,500.00$ & 1500 & & & & & \\
\hline
\end{tabular}


International Journal of Engineering Research and Technology. ISSN 0974-3154, Volume 13, Number 9 (2020), pp. 2347-2358

(C) International Research Publication House. https://dx.doi.org/10.37624/IJERT/13.9.2020.2347-2358

Table (B2): The required sources for optimizing

\begin{tabular}{|c|c|c|c|}
\hline & Min & $\max$ & Opt. results \\
\hline Source 1 & 1000000 & 5000000 & 4220594 \\
\hline source 2 & 1000000 & 5000000 & 2861742 \\
\hline Source 3 & 1000000 & 5000000 & 1020532 \\
\hline
\end{tabular}

\section{APPENDIX C}

Table (C1): The obtained results from the max limit of delivery amounts (node 17=7000KPA, Fsrc $=3 \$ / \mathrm{MMBTU}, \mathrm{Cv}=1090$ $\mathrm{BTU} / \mathrm{ft} 3)$

\begin{tabular}{|c|c|c|c|c|c|c|c|}
\hline & & $\max$ & Sales \$ & & & $\max$ & Sales \$ \\
\hline \multirow{4}{*}{ 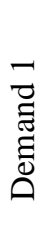 } & A & $1,000,000.0$ & $115,451.65$ & \multirow{4}{*}{ 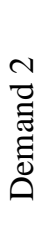 } & $\mathrm{B}$ & $700,000.00$ & $121,224.23$ \\
\hline & $\mathrm{C}$ & $50,000.00$ & $13,469.36$ & & $\mathrm{D}$ & $65,000.00$ & $12,507.26$ \\
\hline & $\mathrm{E}$ & $34,000.00$ & $6,542.26$ & & $\mathrm{~F}$ & $113,000.00$ & $19,569.05$ \\
\hline & $\mathrm{D}$ & $1,500.00$ & 288.63 & & $\mathrm{G}$ & $6,500.00$ & $1,000.58$ \\
\hline \multirow{4}{*}{ 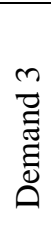 } & $\mathrm{C}$ & $43,000.00$ & $11,583.65$ & \multirow{4}{*}{ 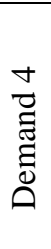 } & $\mathrm{D}$ & $15,000.00$ & $2,886.29$ \\
\hline & $E$ & $20,000.00$ & $3,848.39$ & & $\mathrm{~F}$ & $70,000.00$ & $12,122.42$ \\
\hline & $\mathrm{G}$ & $60,000.00$ & $9,236.13$ & & $\mathrm{~A}$ & $800,000.00$ & $92,361.32$ \\
\hline & $\mathrm{D}$ & $2,500.00$ & 481.05 & & G & $1,200.00$ & 184.72 \\
\hline \multirow{4}{*}{ 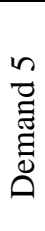 } & $\mathrm{E}$ & $16,000.00$ & $3,078.71$ & \multirow{4}{*}{ 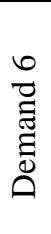 } & $\mathrm{F}$ & $150,000.00$ & $25,976.62$ \\
\hline & $\mathrm{G}$ & $55,000.00$ & $8,466.45$ & & $\mathrm{~A}$ & $300,000.00$ & $34,635.49$ \\
\hline & B & $150,000.00$ & $25,976.62$ & & $\mathrm{C}$ & $75,000.00$ & $20,204.04$ \\
\hline & $\mathrm{D}$ & $2,800.00$ & 538.77 & & $\mathrm{G}$ & $6,000.00$ & 923.61 \\
\hline \multirow{4}{*}{ 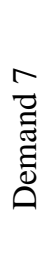 } & $\mathrm{G}$ & $35,000.00$ & $5,387.74$ & \multirow{4}{*}{ 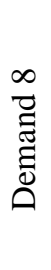 } & A & $800,000.00$ & $92,361.32$ \\
\hline & B & $100,000.00$ & $17,317.75$ & & $\mathrm{C}$ & $60,000.00$ & $16,163.23$ \\
\hline & D & $16,500.00$ & $3,174.92$ & & $\mathrm{E}$ & $55,000.00$ & $10,583.07$ \\
\hline & $\mathrm{F}$ & $1,100.00$ & 190.50 & & $\mathrm{G}$ & $4,500.00$ & 692.71 \\
\hline \multirow{4}{*}{ 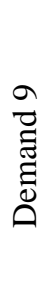 } & B & $60,000.00$ & $10,390.65$ & \multirow{4}{*}{ 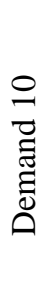 } & $\mathrm{C}$ & $63,000.00$ & $16,971.39$ \\
\hline & $\mathrm{D}$ & $43,000.00$ & $8,274.03$ & & $\mathrm{E}$ & $19,000.00$ & $3,655.97$ \\
\hline & $\mathrm{F}$ & $145,000.00$ & $25,110.73$ & & G & $30,000.00$ & $4,618.07$ \\
\hline & $\mathrm{G}$ & $1,600.00$ & 246.30 & & $\mathrm{D}$ & $4,500.00$ & 865.89 \\
\hline \multirow{3}{*}{ 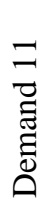 } & $\mathrm{D}$ & $9,000.00$ & $1,731.77$ & \multirow{3}{*}{ 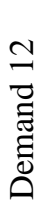 } & $\mathrm{E}$ & $14,000.00$ & $2,693.87$ \\
\hline & $\mathrm{F}$ & $80,000.00$ & $13,854.20$ & & G & $45,000.00$ & $6,927.10$ \\
\hline & A & $1,000,000$ & $115,451.65$ & & $\mathrm{~B}$ & $150,000.00$ & $25,976.62$ \\
\hline
\end{tabular}


International Journal of Engineering Research and Technology. ISSN 0974-3154, Volume 13, Number 9 (2020), pp. 2347-2358

(C) International Research Publication House. https://dx.doi.org/10.37624/IJERT/13.9.2020.2347-2358

\begin{tabular}{|c|c|c|c|c|c|c|c|}
\hline & & $\max$ & Sales \$ & & & $\max$ & Sales \$ \\
\hline & G & $1,300.00$ & 200.12 & & $\mathrm{D}$ & $1,000.00$ & 192.42 \\
\hline \multirow{4}{*}{ 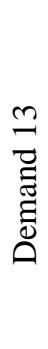 } & $\mathrm{F}$ & $60,000.00$ & $10,390.65$ & \multirow{4}{*}{ 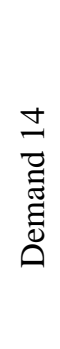 } & $\mathrm{G}$ & $11,000.00$ & $1,693.29$ \\
\hline & A & $1,000,000.0$ & $115,451.65$ & & B & $120,000.00$ & $20,781.30$ \\
\hline & $\mathrm{C}$ & $48,000.00$ & $12,930.58$ & & $\mathrm{D}$ & $60,000.00$ & $11,545.16$ \\
\hline & G & $1,800.00$ & 277.08 & & A & $30,000.00$ & $3,463.55$ \\
\hline \multirow{4}{*}{ 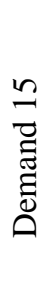 } & A & $1,000,000.0$ & $115,451.65$ & \multirow{4}{*}{ 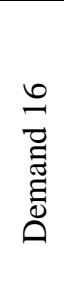 } & B & $38,000.00$ & $6,580.74$ \\
\hline & $\mathrm{C}$ & $43,000.00$ & $11,583.65$ & & $\mathrm{D}$ & $1,500.00$ & 288.63 \\
\hline & $\mathrm{E}$ & $14,000.00$ & $2,693.87$ & & $\mathrm{~F}$ & $85,000.00$ & $14,720.08$ \\
\hline & $\mathrm{G}$ & 850.00 & 130.85 & & A & $850,000.00$ & $98,133.90$ \\
\hline \multirow{4}{*}{ 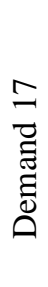 } & $\mathrm{C}$ & $44,000.00$ & $11,853.04$ & & & & \\
\hline & $\mathrm{E}$ & $15,000.00$ & $2,886.29$ & & & & \\
\hline & G & $60,000.00$ & $9,236.13$ & & & & \\
\hline & $\mathrm{D}$ & $1,500.00$ & 288.63 & & & & \\
\hline
\end{tabular}

The total sales gas for max demands =

$1,375,970.04 \$ / \mathrm{h}$

Total transportation tariff for max demands $=$

$145,634.05 \$ / \mathrm{h}$

Total buy gas for max demands

$=$

$1,149,742.54 \$ / \mathrm{h}$

The expected profit for max demands

$=$

$80,593.45 \$ / \mathrm{h}$ 